\title{
Regression Proccess of Marine Hardground in Nanggulan FM., Kulon Progo Mountain, Yogyakarta
}

\author{
$1^{\text {st }}$ Siti Nuraini ${ }^{1}, 2^{\text {nd }}$ Lukmanul Hakim $^{2}$ \\ siti.nuraini@itny.ac.id ${ }^{1}$, luqmanulhaqim@gmail.com ${ }^{2}$
}

Geological Programe of Institut Teknologi Nasional Yogyakarta, Indonesia

\begin{abstract}
A prominent of hardground layer was observed through the Nanggulan beds especially to Watupuru, Songgo and Clumprit Rive, Kulon Progo Montain. The hardground is characterized by a lithified of sea-floor due to sea surface exposure (Wilson and Palmer, 1992; James \& Choquette, 1983). Basically, the hardground layer indicates a coarsening upward succession of calcareous claystone where the coarser carbonate material or grains concentrated to the uppermost of layer meanwhile the lower part tends to be decrease in grain-size. This research will study the character/ behavior of marine hardground whithin Nanggulan Formation during Middle Eocene time, which is reflecting a regression process. By using internal bedding character includes sedimentary texture (colourness, grain size, sorting, fabric, roundess, grain type) and sedimentary structures of Nanggulan beds in Watupuru, Songgo and Clumprit Rivers. Hardground layers in Watupuru exhibited bioclast or grain supported of conglomerate limestone. An intenssively ferroan oxide cement occurred among conglomeratic's carbonate grains and or washed biosparite beds. Burrowing or ichnofossil still preserved as well to the coarser part of hardground layers. It indicates a shallowing depositional environment or regression process occurred during basin sedimentation. Another example of marine hardground related to shell debris layer or coquina. Coquina derived from broken pieces of Mollusc shells (gastropod, bivalve, oysters etc.), embedded to micrite matrix. Coquina hardground appeared to be associated with parallel and lenticular bedding in Watupuru and Clumprit. It suggests may developed under influence of high energy which particularly related to sub-tidal zone. The evidence of coarsening upward of Nanggulan hardground suggests a short regression event might ever occurred during Middle Eocene age.
\end{abstract}

Keywords: hardground, Nanggulan beds, coquina, Watupuru, Songgo, Clumprit, regression.

\section{Introduction}

Recently studies have been documented to Nanggulan Formation regarding its characteristic and behavior in Kulon Progo Mountain, DIY including biostratigraphic study such as calcareous nannoplankton (Saputra \& Akmaluddin, 2015), palynomorf (Polhaupessy, 2009), larger benthic forams (Mark, 1957) and sedimentology/ stratigraphic study (Amijaya et all, 2016). Basically, the Nanggulan Formation indicates a transitional of depositional facies during Middle Eocene age (Rahardjo et all, 1995; Amijaya et all, 2016). It predominantly contains conglomeratic sandstone, lignite, limonite and siderite nodules, shell debris layer, larger foraminifera layer. Nanggulan Formation is also best known as the older sedimentary rock cropped out to the Kulon Progo Mountain. Recently, update data shows a prominent hardground layer appeared within Nanggulan calcareous claystone. Previous discussion only stated the typical of Nanggulan bed relates to the shallow marine environment. In other word, it presumably related to a delta sedimentation (Nuraini, 2018) or estuarine complex (Amijaya et all, 2016). However, it has never been discussed before that Nanggulan beds actually contained many hardground layers there. Knowing the behavior and character of Nanggulan hardgrounds 
will yield a better understanding regarding common shallow-marine process during Paleogene age. By using hardground terminology, hardground layer in Nanggulan Formation exhibites an extensive ferroan oxide cementation of bioclast layer (Tucker, 2003) or indicates a changing grain composition from finer grain to bottom part to be coarser grain bed to the upper part in particular to the carbonate rocks (coarsening upward succession) (Moore, 1989). Furthermore, coarsening upward succession may be used to interpret regression process that reflecting lowering of sea-level (lowstand stage) throughout the study area (Wagoner et al, 1988). Even though previous author has ever mentioned also coarsening-upward characters to Nanggulan beds (Astuti et al., 2016) but it has never been related to regression process (lowering of sealevel) or the occurrences of hardground layer. The purpose of this research to study character/ behavior of marine hardground of Nanggulan Formation which is reflecting a regression process.

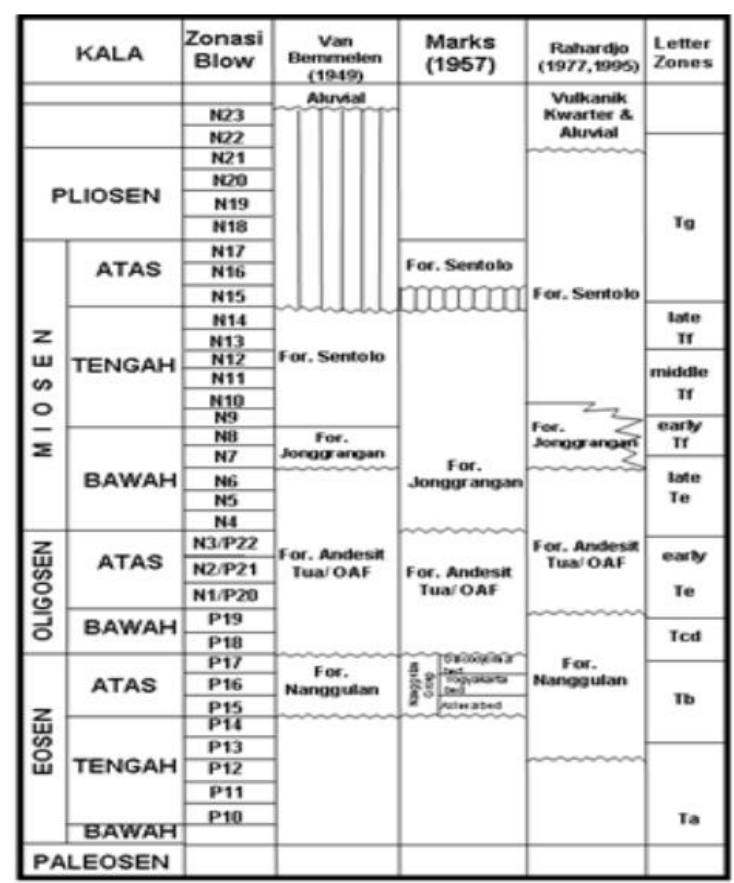

Fig. 1. Regional Stratigraphy of Kulon Progo area

\section{Methodology}

Sedimentology observation has been conducted to study of internally bedding character includes sedimentary texture (color, grain size, sorting, fabric, roundness, grain type) and sedimentary structures by using three geological trajectories (Watupuru, Songgo and Clumprit).

\section{Regional Geology}

Nanggulan Formation in Kulon Progo is best of geological laboratory to learn depositional setting of shallow-marine environment during Middle Eocene age. It located to the southern part of Central Java basin or particularly is known to be Java's Southern Mountains (Bemmelen, 1949). Tectonically, now it located to a fore arc basin. During Middle Eocene to Late Eocene 
age, the basin was filled by calcareous claystone of Nanggulan Formation. Following that time, the basin underwent actively vulcanism which generated Old-Andesite Formation or Kaligesing-Dukuh Formation. during Late Oligocene to Early Miocene. The next event, when the basin was in quiet condition, the Jonggrangan Formation appeared to be shallow-marine carbonate rocks. It reflected a transgressive event occurred during Early Miocene to Late Miocene ages. Subsequently, Jonggrangan limestone gradually changed to be Sentolo Formation as shelfal open-marine to deep-water margin during Late Miocene to Early Pliocene time (Pandita et all, 2016).

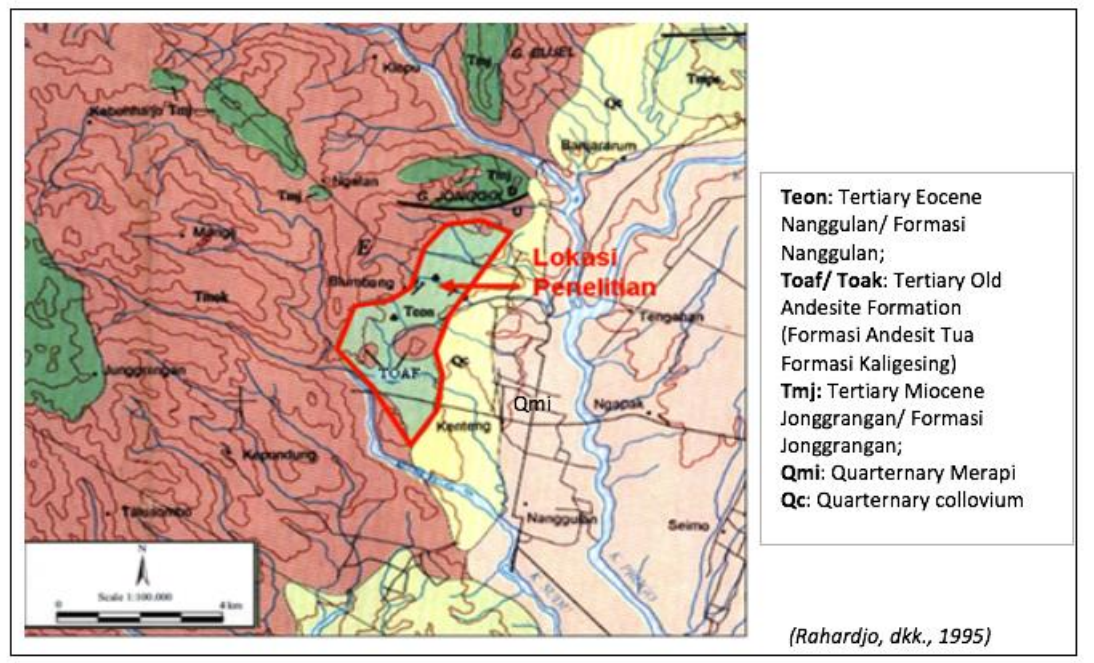

Fig. 2. Geological map of Kulon Progo, DIY

\section{The Results}

\section{1 Conglomeratic Carbonate Hardground}

In Watupuru River, it was observed conglomeratic layer (40 cm thickness) composes various fragments of rocks and shells. Generally, shell fragments derived from shallow water Mollusc such as gastropod, bivalve, oyster etc. whereas the rock fragments indicate well rounded shapes of igneous- and metamorphic rock (andesitic, flint, quartzite etc.). The size of rock fragment ranges from $5 \mathrm{~mm}$ to $10 \mathrm{~mm}$ (gravel to pebble size; Wentworth, 1922). Those are mixed up together within coarse sandstone matrix. Paleocurrents indicates N125- $130{ }^{\circ} \mathrm{E}$ toward to southeastern side of study area.

An extensive ferroan oxide cement presences among the conglomeratic grains. The bed tends to decrease in grain or fragment composition toward the bottom. Then, it becomes a carbonate sparse biomicrite or micrite carbonate rock toward the bottom (Kendall \& Flood, 2011; after Folk, 1959) or becoming finer layer to bottom. This significantly indicates a coarsening upward succession occurred within Nanggulan beds. Ichnofacies or burrowing also develops within light grey of micrite carbonate especially approaching coarser fragment layer. Coal remains are scattered found right below conglomeratic layer (Figure 3). 


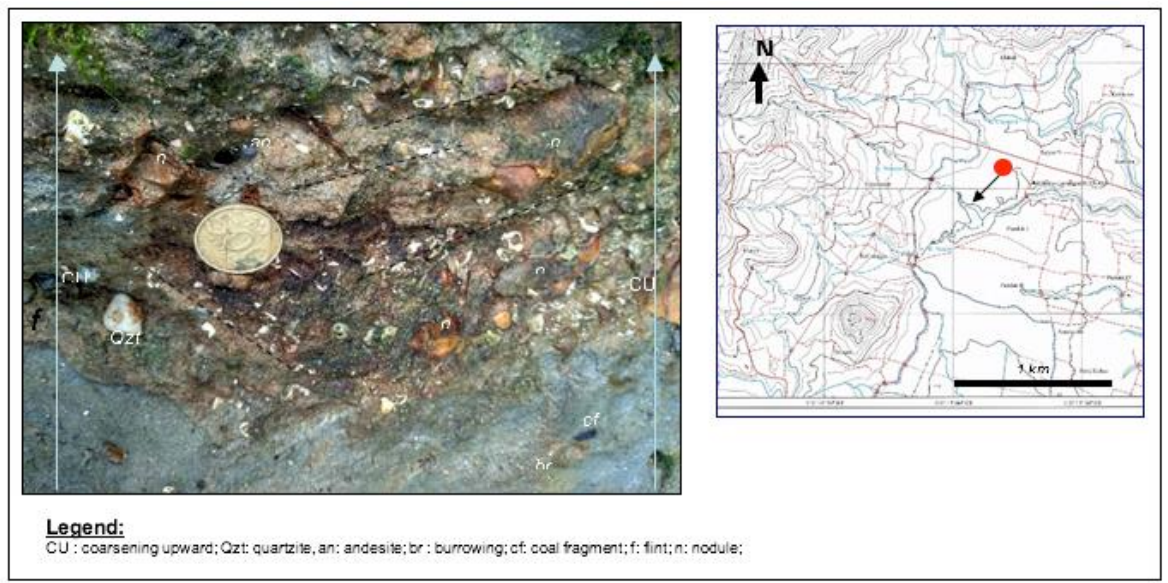

Fig. 3. Conglomeratic carbonate hardground

\subsection{Poorly washed biosparite hardground}

Another hardground fenomena were observed also next to Watupuru and Songgo intersection. The carbonate layer indicates poorly washed biosparite limestone with strong ferroan content in cementation. Previous deposition, the bed composed a uniform shell fragments (possibly bivalve) which embedded to the micrite matrix. Later on, due to bioerosion, those shells that had ever been washed leaved them as shell cast. In fact, these shell cast layer concentrated merely to the upper part. Meanwhile, the carbonate layer tends to decrease in grain composition as micrite or matrix support allochem of carbonate layer to lower part (Kendall \& Flood, 2011, after Folk, 1959). Furthermore, a quite larger of fossil trace (length $15 \mathrm{~cm}$ ) appeared close to the shell cast layer. By looking this, a coarsening upward succession is established to the Nanggulan bed in Watupuru River (Figure 4). Tucker (2003) proposed a similar criterion like this to be a hardground layer which predominantly exhibits well cemented carbonate layer only occurs to upper part rather than to lower part.

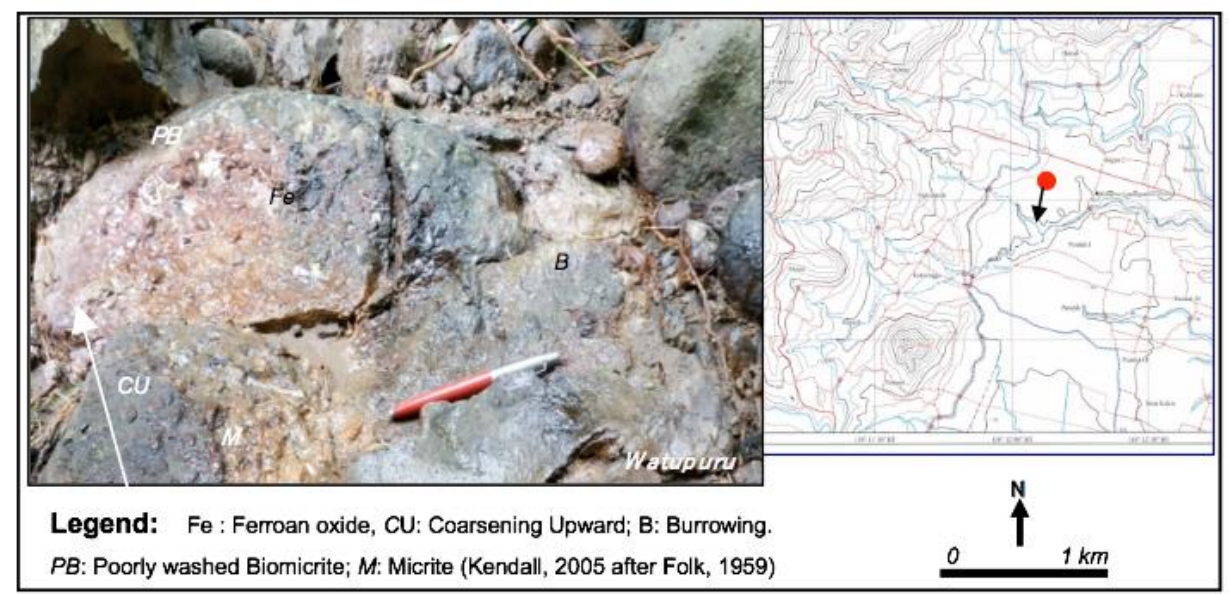

Fig. 4. Poorly washed biosparite hardground 


\subsection{Shell Debris Layer (Coquina)}

Another hardground layer associated to the fossil beds or coquina that has been documented in several places along Nanggulan Formation (Watupuru, Clumprit and Songgo River). The thickness of fossil layer or coquina bed ranges from less than $5 \mathrm{~cm}$ to more than $10 \mathrm{~cm}$, composes of oyster, bivalve, gastropod etc. (Figure 5; Songgo). It is clear among the coquina bed displayed some shells were washed by erosion in Watupuru and Songgo River. Basically, the fossil layer (coquina) indicates a packed biomicrite where the presence of micrite matrix should be considered in supporting of carbonate rock (Kendall \& Flood, 2011 after Folk 1959).

Bed character of coquina mostly exhibits a single layer but in certain location shows a repetition coquina bed in thickness $\sim 1 \mathrm{~cm}$, such in Watupuru (Figure 5; Watupuru). The occurrences of micrite carbonate rock for about $1 \mathrm{~cm}$ thickness clearly separated each coquina there. Meanwhile, in Clumprit beds, a prominent lenticular lamination develops in beginning before coquina bed. Enrichment of ferroan oxide was reflected by light brown color appeared between cross lenticular lamination in particular to the Clumprit beds. Furthermore, there still a shell intact preserved within coquina bed (Figure 5; Clumprit).

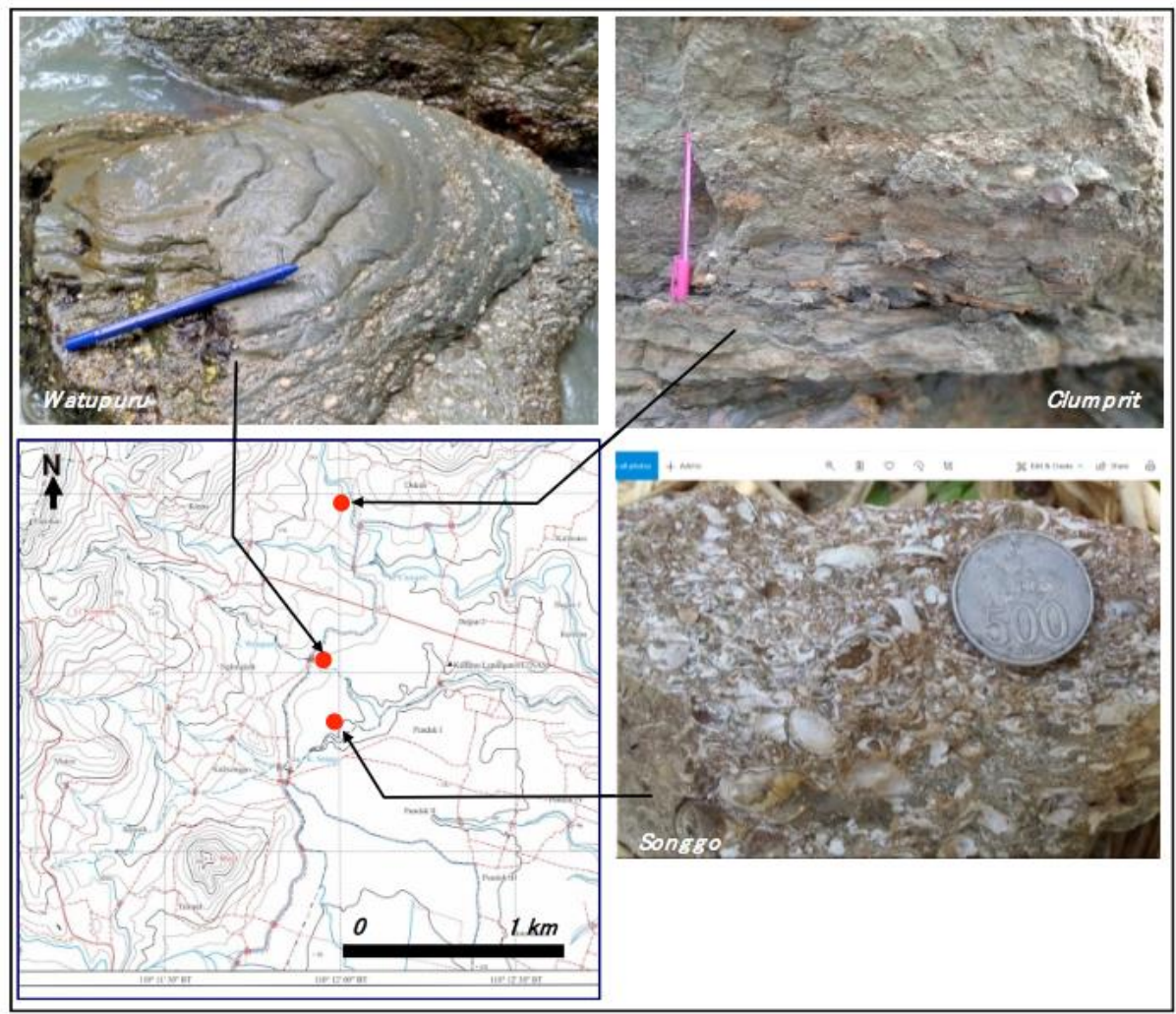

Fig. 5. Shell debris layer or coquina appears in several part of Nanggulan beds. 


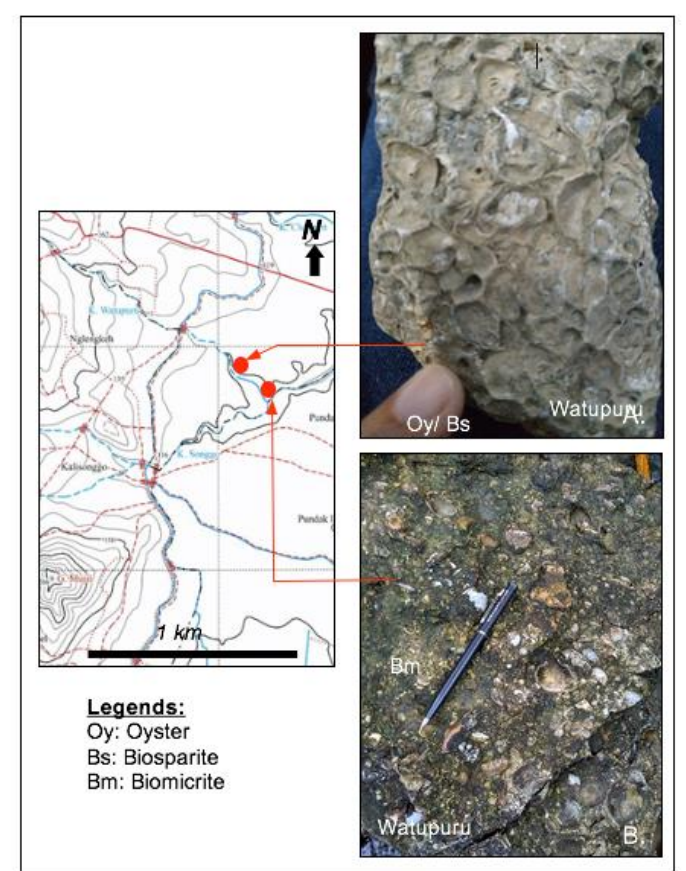

Fig. 6. Hardground layer of oyster fossils in Watupuru

\section{Discussion}

\subsection{Regression Event}

Several hardgrounds that have been collected to Nanggulan Formation indicates conglomeratic carbonate layer, poorly washed biosparite hardground and shell debris layer (coquina). These hardground layers showed coarser materials/ fragments or grains concentrated only to the uppermost of layers. However, bed character toward bottom tends to be decrease in grain-sized. By looking of this, it will be interpreted as a shallowing upward succession or coarsening upward of bedding character. For some reasons, it is also known to be a reverse graded bedding. This occurred within the calcareous claystone of Nanggulan's bed which obviously represented a lowering of sea-level or regression process (Wagoner et al, 1990). Some clues suggested an exposure event occurred during Nanggulan sedimentation by the evidence of highly iron oxide concentration among conglomerate carbonate grains and washed biosparite beds (Figure $3 \& 4$ ). These layers significantly imply carbonate hardground which commonly found to shallow marine of carbonate shelf limestone (Moore, 1989). Tucker (2003) pointed out as well the hardground surface also exhibits a well cemented carbonate bed with developing of animal tracts or ichnofossil to the upper surface such in Watupuru location (Figure 4).

A stacked shell debris in Nanggulan beds (Watupuru, Songgo and Clumprit) composes broken pieces of mollusc tests such as oyster, bivalves, gastropod etc. which also named as coquina. Coquina bed in many locations were characterized by a repetition bed for about $1 \mathrm{~cm}$ between shell debris and micrite carbonate matrix (Figure 5/ Watupuru). In this situation, the depositional presumably was under controlled by a changing situation between high energy to be quite energy environment vice versa. It strongly suggested it develops under influence of high wave or current energy, usually related to tide or even storm (Burchette \& Wright, 1992) (Figure 5). The occurrences of sedimentary structures: lenticular to flaser bed, trough cross 
bedded, bi-polar cross bedded, mud drape, sand clasts, double mud layer etc. to the Nanggulan beds indicated as a product of tidal environment such as shoal, barrier bar etc. (Figure 7). In Clumprit beds, a prominent lenticular lamination develops in beginning before coquina bed. Enrichment of ferroan oxide was reflected by light brown color appeared between cross lenticular lamination in particular to the Clumprit beds. Furthermore, there still a shell intact preserved within coquina bed. It probably occurred just after the end of tide phase, where flow's tail perfectly wrapped an individual shell behind (Figure 5; Clumprit). Coquina bed also represents hardground layer particularly related to the sub-tidal zone. Moore (1989) pointed out the marine hardground commonly associated to sub-tidal zone which facing straight forward to the open-marine (Walker, 1984). This conclusion was supported by the occurrences of ubiquitous trough cross bed next to it.

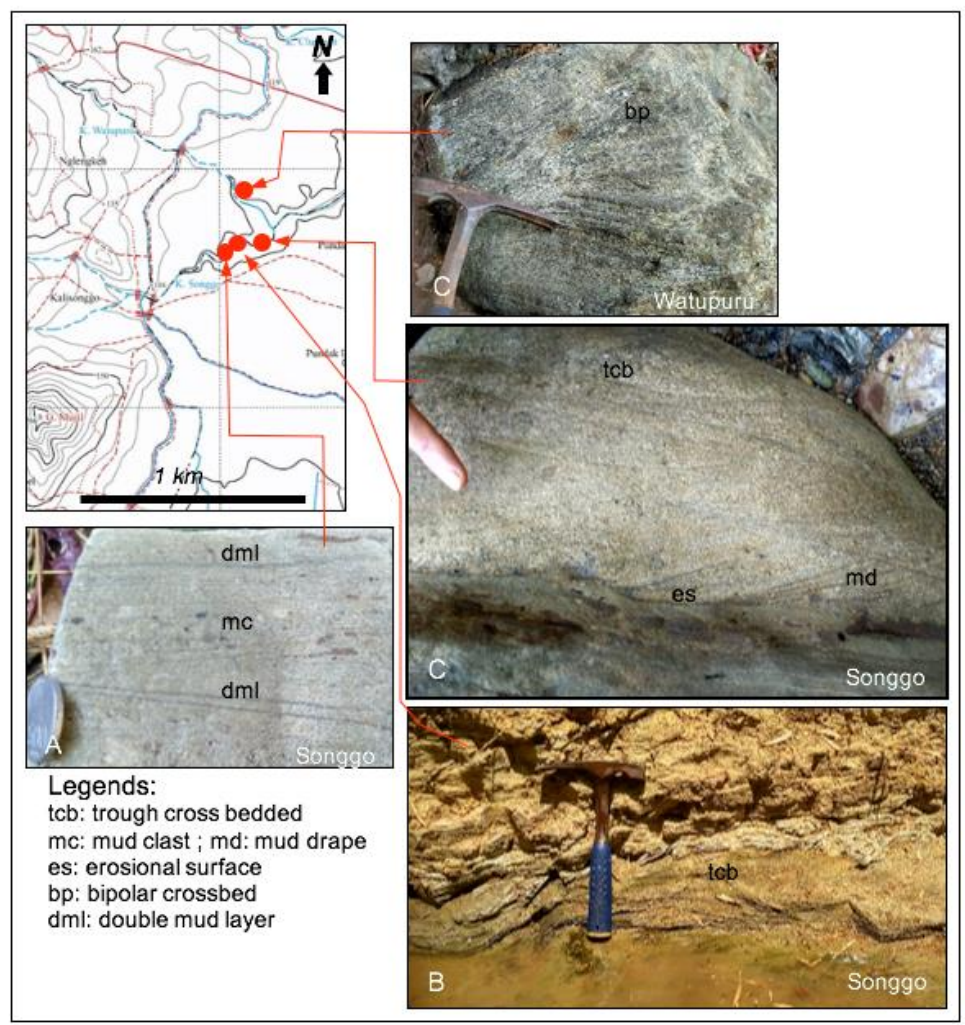

Fig. 7. Sedimentary structures of Nanggulan bed

\section{Conclusion}

Hardground phenomena has been documented recently to the Nanggulan Formation in Watupuru, Songgo and Clumprit rivers. One of most indicators of hardground is a lithified of sea-floor due to sea-surface exposure (Wilson and Palmer, 1992; James \& Choquette, 1983. The Nanggulan hardground was preserved within a coarsening upward bed which associates to increasing grain size or fossil fragments to the top of layers. While to bottom part, the grains or materials decrease gradually within 15 to $20 \mathrm{~cm}$ bed thickness. Coarser grains are composed by fragment ranges from less than $5 \mathrm{~mm}$ (pebble) until up to $10 \mathrm{~mm}$ (gravel) in size (Wenworth, 1992). Those grains presence within poorly sorted of micritic matrix. In Watupuru, grain 
supported of conglomeratic bed indicates highly ferroan oxide content in cementation process. The conglomerate fragments derived from metamorphic and igneous rock such as quartzite, cherts and andesitic rocks, which mixed up to the skeletal fragments such as gastropod, bivalve, oyster etc. (Figure 3). Furthermore, some of bioclast was removed by erosion leaved a cast behind such in Watupuru River (Figure 4). By looking of those evidences, mostly the coarsening upward succession of Nanggulan beds associated with animal tract or burrowing (Figure $3 \& 4$ ). However, shell debris or coquina bed in several locations also represents hardground layer that associated with parallel- and lenticular beddings (Figure 5). Moore (1989) has ever mentioned regarding the coarsening upward of carbonate limestone is common occurs to the shelf areas.

The evidence of coarsening upward of Nanggulan beds suggest as shallowing upward of marine sedimentation during Middle Eocene age. In other word, regression process may impact much in the area close to shore-line or marginal marine such as Nanggulan area. Tide is not the only one energy that ever influenced the Nanggulan sedimentation. For example, wave or storm energy also plays important role in modifying the entire Nanggulan sedimentation (Nuraini, 2018). Although, in general Nanggulan beds represent transgressive delta sequence but actually a brief regression process more likely had ever developed there as well.

\section{Acknowledgment:}

I thank to my institution ITNY (colleagues, friends and students) in supporting this study by giving ideas and helping field works.

\section{References}

[1] Amijaya, H., Adibah, N., Ansory, A.Z.A., 2016, Lithofasies and Sedimentation of Organic Matter in Fine Grained Rocks of Nanggulan Formation in Kulon Progo, Yogyakarta, Journal of Applied Geology 1 (2), 82-88.

[2] Astuti, B.S., Humantoro, R., Hidayat, M., Kusuma, H.D., 2016, Analisis Struktur Geologi Jalur Kali Watupuru dan Kali Songgo Daerah Degan Kulon Progo, Dan Implikasinya Terhadap Penyebaran Batpasir Kuarsa Formasi Nanggulan yang Berpotensi Sebagai Reservoir, Proceesing Teknik Geologi, Universitas Padjadjaran, Bandung.

[3] Boyd, R., Dalrymple, R. and Zaitlin, B.A., 1992, Classification of Clastic Coastal Depositional Environments, Sedimentary Geology, 80, 139-150.

[4] Burchette, T.P. and Wright, V.P., 1992, Carbonate ramp depositional systems, in B.W. Sellwood (Editor), Ramps and Reefs. Sediment, Geol., 79: 3-57.

[5] Folk, R.I., 1959, Practical Petrographic Classification of Limestones, Bull. American Association Petroleum Geologist, 43, 1-38.

[6] James, N.P. dan Choquette, P.W., 1983, Diagenesis 6, Limestone, The sea floor diagenetic environment, Geosci. Can., 0, 162-179.

[7] Kendall, C.G.St., Flood, P., 2011, Classification of Carbonate in Encyclopedia of Modern Coral Reefs, Structure Form and Process, Ed. David Hopley, Earth Science Series, Springer, 193-198 pp.

[8] Marks, P., 1957. Stratigraphy Lexicon of Indonesia, Publikasi Keilmuan np. 31, Seri Geologi, Pusat Jawatan Geologi Bandung.

[9] Moore, Clyde H., 1989, Carbonate Diagenesis and Porosity, Development in Sedimentology 46, Elsevier, 338. 
[10] Nuraini, S., 2018, Intensitas Pengaruh Pasang-surut dan Pengaruh Badai pada Model Delta Nanggulan, Pegunungan Kulon Progo, Yogyakarta, Prosiding Seminar Nasional ReTII ke 13, 277-284 pp.

[11] Pandita, H., Pambudi, S., Winarti, 2006, Kajian biostratigrafi dan Fasies Formasi Sentolo di Daerah Guluhrejo dan Ngaran Kabupaten Bantul untuk Mengidentifikasi Keberadaan Sesar Progo, Proceesing Teknik Geologi, Universitas Padjadjaran, Bandung.

[12] Polhaupessy, A.A, 2009, Pollen Paleogen-Neogen dari Daerah Nanggulan dan Karangsambung, Jawa Tengah, JSDG, vol 19, no.5.

[13] Rahardjo, W., Sukandarrumidi, Rosidi, H.M.D, 1995, Peta Geologi Yogyakarta, Jawa, skala 1;100,000, Pusat Penelitian dan Pengembangan Geologi, Bandung.

[14] Saputra, R., Akmaluddin, 2015, Biostratigrafi Nonnofossil Gampingan Formasi Nanggulan Bagian Bawah Berdasarkan Batuan Inti Dari Kecamatan Girimulyo dan Kecamatan Nanggulan, Kabupaten Kulon Progo, D.I.Yogyakarta, Proceeding Seminar Nasional Kebumian ke 8, Universitas Gajahmada.

[15] Tucker, M.E., 2003, Sedimentary Rocks in the Field, 3rd ed. John Wiley \& Sons Ltd,West Sussex, England. 234 pp.

[16] Van Bemmelen, R.W., 1949, The Geology of Indonesia,1A, The Hague, Martinus Nijhoff, 732pp.

[17] Van Wagoner J.C., Mitchum, R.M., Campion, K.M., Rahmanian, V.D., 1990. Siliciclastic Sequence Stratigraphy in Well Logs, Cores, and Outcrops: Concept for High-Resolution Correlation of Time and Facies, AAPG Methods in Exploration Series, no. 7, AAPG, Tulsa, Oklahoma 74101 U.S.A.

[18] Walker, R. G., 1984, Facies Models, Geoscience Canada, v.2, 317p.

[19] Wentworth, C.K., 1922. A Scale of Grade and Class Terms for Clastic Sediments, The Journal of Geology, v. 30 (5), 377-392.

[20] Wilson, M.A.; Palmer, T.J., 1992, Hardgrounds and hardground faunas, University of Wales, Aberystwyth, Institute of Earth Studies Publications. 9: 1-131. 